\title{
ECOLOGY AND DISTRIBUTION OF RARE LICHENS OF THE CHUVASH PRISURYE
}

(C) 2020

Sinichkin Evgeny Arkadyevich, researcher

Cheboksary Branch of the Main Botanical Garden named after N.V. Tsitsin of the Russian Academy of Sciences (Cheboksary, Russian Federation)

Bogdanov Gennady Alekseevich, senior researcher

State Nature Reserve «Bolshaya Kokshaga» (Yoshkar-Ola, Russian Federation)

Dimitriev Aleksandr Veniaminovich, candidate of biological sciences, director

Cheboksary Branch of the Main Botanical Garden named after N.V. Tsitsin of the Russian Academy of Sciences (Cheboksary, Russian Federation)

Abstract. The paper contains data about 20 new and rare lichens of the Chuvash Prisurye. 10 lichens are new for the Chuvash Republic, 5 species are new for the Privolzhskaya Upland. The identified lichen species are indicators of old-growth, undisturbed and intact forests that have been preserved in specially protected natural areas. There are 18 species in the National Park "Chuvash varmane» and 8 species in the State Nature Reserve «Prisursky». Geographical coordinates, distribution features in neighboring regions, ecological-substrate and phytocenotic confinement and age status are indicated for each species. The information on the ecology and distribution of rare lichen species is updated. 18 species of lichens (Bryoria nadvornikiana, Br. trichodes, Cetrelia olivetorum, Cresponea chloroconia, Evernia divaricata, Heterodermia speciosa, Leptogium cyanescens, L. saturninum, Nephroma parile, Scytinium subtile, Sc. teretiusculum, Sc. tenuissimum, Usnea dasopoga, Us. florida, Us. subfloridana, Ramalina thrausta, $R$. sinensis, Xanthomendoza ulophyllodes) are proposed in the new edition of the Red book of the Chuvash Republic with the Status III - rare species. 2 lichen species (Cetraria ericetorum, Lobaria pulmonaria) are classified as category II-vulnerable species, declining in number.

Keywords: lichens; lichen flora; rare species; plant communities; forest; pine forests; linden forests; aspen forests; birch forests; area; Chuvash Prisurye; state nature reserve «Prisursky»; National Park «Chuvash varmane»; Alatyrsky District; Ibresinsky District; specially protected natural territory; Red book; Chuvash Republic.

$* * *$

УДК 574.2/474:502.31/35/37:504.05/062/75.06

DOI 10.24411/2309-4370-2020-11116

Статья поступила в редакцию 06.01.2020

\section{ЭКОЛОГИЧЕСКАЯ ОЦЕНКА САНИТАРНЫХ ПОКАЗАТЕЛЕЙ ДРЕВЕСНЫХ РАСТЕНИЙ В ПРИРОДНЫХ И ТЕХНОГЕННЫХ УСЛОВИЯХ}

(C) 2020

Сираева Ирина Салаватовна, аспирант кафедры ботаники и экологии

Саратовский национальный исследовательский государственный университет имени Н.Г. Чернышевского

(2. Саратов, Российская Федерация)

Ларионов Максим Викторович, доктор биологических наук, доцент, профессор кафедры биологии и экологии

Балашовский институт (филиал) Саратовского начионального исследовательского государственного университета имени Н.Г. Чернышевского (г. Балашов, Саратовская область, Российская Федерация)

Ларионов Николай Викторович, кандидат биологических наук, директор

Котельниковская средняя общеобразовательная школа № 2

(2. Котельники, Московская область, Российская Федерачия)

Солдатова Валерия Викторовна, аспирант кафедры ботаники и экологии

Громова Татьяна Сергеевна, аспирант кафедры ботаники и экологии

Ермоленко Анна Сергеевна, аспирант кафедры ботаники и экологии

Саратовский национальный исследовательский государственный университет имени Н.Г. Чернышевского

(2. Саратов, Российская Федерация)

Кулагина Екатерина Юрьевна, кандидат биологических наук, доцент кафедры биологии и экологии Владимирский государственный университет

имени Александра Григорьевича и Николая Григорьевича Столетовых (2. Владимир, Российская Федеращия)

Аннотация. Установлены и проанализированы показатели санитарного состояния древесных растений в условиях естественных и искусственных экосистем Воронежской и Саратовской областей. В пригородных экосистемах территории исследований состояние древесных растений определено на уровне слабой поврежденности. В пригородных районах к городу Балашову с наибольшим хозяйственно-техносферным потенциалом древесные растения достигают средней (умеренной) степени повреждений. В удаленных относительно сохранившихся экосистемах (контрольные данные) состояние этих организмов соответствует слабому эколого-диагностическому критерию. По выявленным средним арифметическим санитарным показателям в Воронежском регионе наилучшим состоянием характеризуются древесные растения в экосистемах Новохоперска и Грибановского, в Саратовском - в Турках и Самойловке. Также выявлены достоверные различия в средне- 
арифметических параметрах санитарного состояния представителей этой группы растений дифференцированно функциональным зонам. Наибольшие значения повреждений характерны древесным растениям в составе урбоэкосистем индустриальных зон. Максимальная опасность для древесных растений отмечена в пределах этих зон в Поворино, Борисоглебске, Балашове со среднеарифметическими значениями поврежденности этих организмов высокого уровня. Существенное беспокойство вызывает также пораженность анализируемой группы организмов этих городов в составе экосистем зон селитьбы. Результаты оценки санитарного состояния древесных растений целесообразно использовать в качестве научной базы в озеленительных, эколого-защитных и лесовосстановительных работах. Предложены меры по улучшению состояния древесных растений в различных типах экосистем территории исследований. По данным санитарного состояния этих организмов можно определять пределы устойчивости экологических каркасов и дифференцировать параметры экологической комфортности для местного населения в разных территориальных категориях.

Ключевые слова: муниципальные районы Воронежской области; муниципальные районы Саратовской области; естественные экосистемы; искусственные экосистемы; зоны рекреации; зоны селитьбы; индустриальные зоны; санитарное состояние древесных растений; значения и уровни ослабления растений; территориальные различия в жизнеспособности растений; тренды биологической устойчивости растений; качество окружающей среды; значения экологической комфортности для жителей; актуальность мер охраны насаждений.

\section{Введение}

Ведущее значение в формировании наземных экологических каркасов на территории Воронежской и Саратовской областей отведено древесным растениям в составе как природных (формируют организационную структуру и функциональность природно-экологических каркасов), так и искусственных экологических систем (определяют организационную основу и эффективность экокаркасов городов и других природно-хозяйственных комплексов). Параметры состояния древесных растений, являющихся важнейшими и постоянными автотрофными компонентами экосистем, информируют также о состоянии образуемых ими сообществ, качестве окружающей среды и об уровне экологической комфортности урбанизированных территорий для местного населения. Территория исследований включала восток и северо-восток Воронежской области, северо-запад, запад и юго-запад Саратовской области, находящиеся на Окско-Донской равнине.

Природно-климатические условия Окско-Донской равнины определяются общей спецификой ландшафтной организации [1]. Преимущественный характер рельефа плоскоместный, с чередованием террасированных долин. Выражены пойменные комплексы. Междуречные пространства относительно выравнены, с небольшими колебаниями высот [2; 3]. На этих пространствах развились лугово-степные и в основном степные экосистемы. Большая часть степных комплексов (за исключением оврагов, балок, перекрытий, промоин) занята растениеводческими угодьями, а также в меньшей степени - сенокосами и пастбищами [4; 5]. Максимальный модуль антропогенной нагрузки концентрируется в границах населенных пунктов, прежде всего, в центрах муниципальных районов. Совокупная техногенная нагрузка в поселениях Воронежской и Саратовской областей дифференцируется по основным функциональным зонам: от слабой (рекреационные объекты) до сильной (индустриальные зоны).

Фактическое санитарное состояние древесных растений представляет комплексный параметр, свидетельствующий об особенностях их жизнедеятельности, жизнеспособности и биологической устойчивости в соответствующих условиях местообитаний [6-11]. Санитарное состояние древесных растений определяет параметры их декоративности [11-13].
Явный дефицит сведений о санитарном состоянии древесных растений в естественных и рукотворных экосистемах на указанной территории [14; 15] определяет актуальность и значимость реализованных исследований и сформулированных выводов.

Для того чтобы проанализировать современное состояние древесных растений в составе природных и искусственных экосистем, в течение летних полевых сезонов 2011-2019 гг. проведены наблюдения и исследования на предмет идентификации и диагностики основных санитарных показателей древесных растений. Обследовались древесные насаждения разных категорий использования в населенных пунктах - центрах административных районов. Последние дифференцировались, согласно принятым в отечественной градопланировочной практике требованиям [16], по основным функциональным зонам - рекреационным, селитебным, индустриальным. В пригородных зонах исследованиями охвачены древесные растения, произрастающие в составе экосистем естественного происхождения и находящиеся под преимущественной рекреационной нагрузкой. Участки природных лесных экосистем без визуальных признаков активного лесопользования и с учетом лесоустроительных материалов находились на удалении от районных центров. Они служили контрольными пунктами экологического мониторинга состояния древесных растений.

Цель исследований: определение и экологическая оценка санитарных параметров древесных растений, произрастающих на функционально разных урбанизированных территориях Воронежского и Саратовского областей регионов, результаты которой свидетельствуют о параметрах жизнеспособности, биологической устойчивости и значениях биоэкологического потенциала. Эти данные в роли научно-теоретической основы позволят решать актуальные задачи по качественной экологической диагностике состояния объектов окружающей среды в этих регионах, а также по оптимизации видового состава и структуры урбанизированных экосистем, их защите и эффективному менеджменту в различных функциональнопланировочных зонах.

\section{Методы исследований}

Фиксировались механические повреждения надземных органов древесных растений, подверженность их воздействию вредителями, болезнями, усыханию. Комплекс данных признаков, обусловливаю- 
Сираева И.С., Ларионов М.В., Ларионов Н.В., Солдатова В.В., Громова Т.С., Ермоленко А.С., Кулагина Е.Ю. Экологическая оценка санитарных показателей древесных растений в природных и техногенных..

щих жизнеспособность и устойчивость этой группы растений [17-19], анализировался с учетом методических рекомендаций по интерпретации уровней деградации растений в процентных долях [20;21]. По основным санитарным показателям нарушений осуществлена обобщенная оценка состояния древесных растений, произрастающих в составе искусственных экосистем (насаждений) на различных функционально организованных территориях населенных пунктов районного значения, в их пригородных зонах и в составе естественных экосистем. Параметры санитарного состояния последних использованы в анализе исследовательских материалов в качестве контрольных данных. В анализе использованы растения в среднегенеративной стадии индивидуального развития. Результаты исследований подвергнуты статистической обработке [22]. Их средние арифметические значения получены в 95\%-м интервале. Итоговые данные экологической оценки представлены в графическом виде.

\section{Результаты исследований}

В естественных и искусственных экосистемах Воронежского и Саратовского регионов устанавливались показатели санитарного состояния у Acer platanoides L., A. tataricum L., Betula pendula Roth, B. alba L., Fraxinus excelsior L., Quercus robur L., Malus sylvestris (L.) Mill., Pinus sylvestris L., Padus avium Mill., Cerasus fruticosa Pall., Salix alba L., S. fragilis L., S. pentandra L., S. triandra L., Tilia cordata Mill., Ulmus laevis Pall., U. minor Mill., Sorbus aucuparia L. Эти виды являются аборигенами в местной флоре. Также они использованы в городском и поселковом озеленении (совместно с растениями-интродуцентами).

Средние арифметические результаты санитарного состояния объектов исследований в экосистемах Воронежской области графически представлены далее на рисунке 1 . В качестве поселений в данной работе рассмотрены административные центры муниципальных районов. Контрольные значения санитарных показателей древесных растений также определены в каждом муниципальном районе.

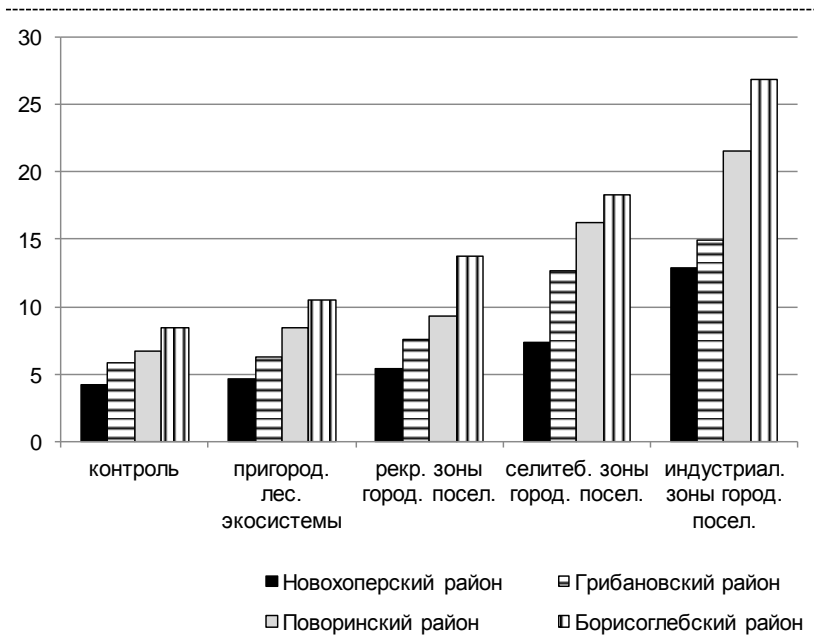

Рисунок 1 - Распределение

значений поврежденности древесных растений в муниципальных районах Воронежской области, \%

Данный рисунок демонстрирует следующее. Минимальные средневзвешенные значения повреждений древесных растений выявлены в условиях относительно сохранившихся природных экосистем, использованных в роли контроля: 4,2 $\pm 0,14$ (Ново- хоперский район), 5,9 $\pm 0,21$ (Грибановский район), $6,7 \pm 0,27$ (Поворинский район), $8,4 \pm 0,32 \%$ (Борисоглебский район). В среднем в данных районах слабый уровень повреждений диагностируемых организмов. Максимальные проценты повреждений характерны древесным растениям, произрастающим в индустриальных зонах населенных пунктов: от умеренной поврежденности $(12,9 \pm 0,38$ в г. Новохоперск, $14,9 \pm 0,36$ в п.г.т. Грибановский) - до сильной поврежденности $(21,6 \pm 0,58$ в г. Поворино, $26,9 \pm 0,82$ в г. Борисоглебск). Параметры повреждений анализируемой группы растений в экосистемах пригородных районов и зон рекреации (преимущественно слабый уровень поврежденности, кроме Борисоглебска с умеренной поврежденностью древесных растений), зон селитьбы (умеренная поврежденность древесных растений за исключением Новохоперска со слабым значением этого эколого-диагностического критерия) занимают промежуточные положения. Причем во всех функциональных зонах наибольшие показатели повреждений выявлены у древесных растений, произрастающих в зеленых (буферных) зонах вдоль автодорог.

Для исследованной территории Воронежского региона по данным анализа выявлено возрастание биологической устойчивости растений в следующем ряду: B. pendula Roth, P. sylvestris L., B. alba L., P. avium Mill., S. fragilis L., A. platanoides L., T. cordata Mill., S. aucuparia L., S. triandra L., S. pentandra L., Q. robur L., S. alba L., U. laevis Pall., A. tataricum L., U. minor Mill., F. excelsior L., M. sylvestris (L.) Mill., C. fruticosa Pall.

Также гистограмма данного рисунка показывает тренд в сторону ослабления древесных растений в ряду от рекреационных до индустриальных зон в границах поселений. Полученные средние арифметические значения санитарных показателей состояния растений статистически достоверны ( $p<5 \%, t>3)$.

На рисунке 2 отражены результаты определения показателей повреждений древесных растений, произрастающих в составе разных типов экосистем в Саратовской области. По аналогии с предыдущим регионом, здесь также для каждого муниципального района выбраны свои контрольные участки.

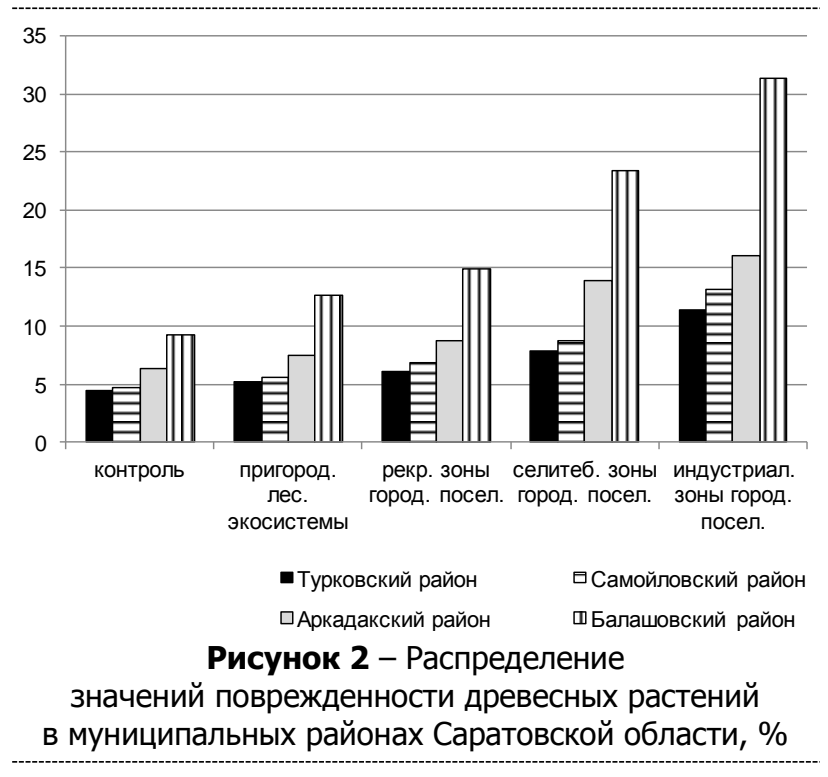

Из рисунка 2 следует, что наибольшие среднеарифметические значения показателей повреждений 
Сираева И.С., Ларионов М.В., Ларионов Н.В., Солдатова В.В., Громова Т.С., Ермоленко А.С., Кулагина Е.Ю. Экологическая оценка санитарных показателей древесных растений в природных и техногенных...

Общая биология Экологическая оценка санитарных по зонам: $11,4 \pm 0,33$ (р.п. Турки, умеренная поврежденность рассматриваемых организмов), 23,2 $\pm 0,74$ (п.г.т. Самойловка, сильный уровень поврежденности), 16,1 0,53 (г. Аркадак, умеренная поврежденность), 31,2 \pm 0,81 (г. Балашов, высокая поврежденность растений). Наименьшие (слабый уровень) повреждения установлены у древесных растений, произрастающих в составе естественных экосистемах (контрольные участки): 4,5 \pm 0,16 (Турковский район), 4,7 $\pm 0,19$ (Самойловский район), 6,3 \pm 0,24 (Apкадакский район), 9,2 $\pm 0,31$ (Балашовский район). Аналогично, как и в Воронежском регионе, в Саратовском регионе значения повреждений рассматриваемой группы растений в пригородных зеленых и рекреационных (преимущественно слабый уровень поврежденности древесных растений за исключением Балашова с умеренным уровнем данного диагностического показателя), селитебных (слабая (Турки, Самойловка) и умеренная (Аркадак, Балашов) поврежденность растений) зонах занимают срединное положение. Максимально ослабленными являются древесные растения в экосистемах буферных озелененных структур во всех функциональных зонах, особенно в пределах индустриальных зон. Наиболее высокие значения повреждений проявляются у древесных растений из состава автотранспортных зон.

По среднестатистическим результатам экологической оценки растений сформирован восходящий ряд по усилению их устойчивости: P. sylvestris L., B. pendula Roth, B. alba L., S. fragilis L., P. avium Mill., T. cordata Mill., A. platanoides L., S. aucuparia L., Q. robur L., S. triandra L., S. pentandra L., S. alba L., A. tataricum L., U. laevis Pall., F. excelsior L., U. minor Mill., C. fruticosa Pall., M. sylvestris (L.) Mill. Представленные ряды древесных растений по повышению совокупных параметров состояния и жизнеспособности в определенной степени отражают тенденцию к снижению их биологической устойчивости в зависимости от видовых биоэкологических особенностей и экологического состояния мест произрастания в Воронежской и Саратовской областях.

Общей тенденцией в данном регионе, как и в Воронежской области, является возрастание параметров повреждений древесных растений в урбоэкосистемах от рекреационных объектов к индустриальным зонам. Различия в значениях процентов повреждений древесных растений, произрастающих в разных типах экосистем, с контрольными данными, статистически значимы $(p<5 \%, t>3)$.

Наибольшие повреждения древесных растений отмечены в районных центрах с максимальным хозяйственно-производственным потенциалом в сравнении с остальными исследованными поселениями. В Воронежской области таковыми являются г. Поворино, г. Борисоглебск, в Саратовской - г. Аркадак, г. Балашов. В этих городах в первую очередь очевидна необходимость в действенных мерах по улучшению санитарного состояния.

Анализ результатов исследований позволил дифференцировать виды растений по устойчивости к комплексу санитарных показателей деградации. Высокоустойчивыми видами явились M. sylvestris (L.) Mill., C. fruticosa Pall., низкоустойчивые растения B. pendula Roth, P. sylvestris L., B. alba L. Остальные Самарский научный вестник. 2020. Т. 9, № 1 (30) виды на территории исследований обладают средним уровнем устойчивости. Эта дифференциация отражает, как проявление состояния и устойчивости к абиотическим факторам, так и к биотическим деградационным (ослабляющим) воздействиям, обусловленным соответствующими урбано-техногенными условиями в разных функциональных зонах. В муниципальных районах обоих регионов тренды санитарного состояния и устойчивости оказались схожими, что можно объяснить относительной близостью их расположения друг к другу, относительно схожими размерами, сходной функционально-планировочной организацией, спецификой хозяйственной эксплуатации и антропогенной нагрузки, общим характером природно-климатических факторов.

Данные о значении санитарных показателях состояния древесных растений полезно использовать в качестве научной основы в озеленительной практике рассмотренных муниципальных районов Воронежской и Саратовской областей. Близость к населенным пунктам природных экосистем, включающих разные виды растений, в том числе из состава проанализированных в данной работе, обеспечивает необходимые ресурсы для широкого введения этих растений в культуру в городские и пригородные территории. Установленные значения санитарных параметров их состояния в зависимости от экологических особенностей мест произрастания совместно с другими экологическими критериями (показателями роста и развития, специфики фенологических фаз, эколого-защитными свойствами, декоративными качествами, биоценотическими ролями) и требуемыми агротехническими приемами целесообразно применить в качестве системно-методической и научной основы надзора за состоянием, индивидуальным и групповым (применительно к группировкам особей, видов) развитием на экологически неоднородных территориях, экологическими, планировочными, хозяйственными и социальными функциями древесных насаждений.

\section{Выводы и предложения}

Анализ полученных данных позволил сформулировать следующие основные вblводыl.

1. По существу, в пределах территории исследований в Воронежской и Саратовской областях средние арифметические значения результатов демонстрируют определенный тренд в сторону существенного ухудшения санитарного состояния древесных растений в селитебных и особенно в индустриальных зонах городских поселений. В пределах этих функциональных зон суммарный техногенный прессинг способствует ослаблению биологической устойчивости рассмотренной группы растений, что отмечено на протяжении всего периода наблюдений и исследований. Во всех муниципальных районах полученные среднеарифметические значения статистически значимы. Очевиден явный дефицит деятельности по уходу за насаждениями, особенно близи зон инженерной инфраструктуры, коммунально-складских и производственных территорий.

2. В рекреационных зонах исследованных поселений средние арифметические значения поражений древесных растений достоверно превышали соответствующие контрольные параметры. Сказывается наличие комплексной рекреационно-хозяйственной нагрузки, способствующей ослаблению состояния дан- 
Сираева И.С., Ларионов М.В., Ларионов Н.В., Солдатова В.В., Громова Т.С., Ермоленко А.С., Кулагина Е.Ю.

Экологическая оценка санитарных показателей древесных растений в природных и техногенных..

Общая биология

ных организмов. В существенной мере влияют также недостаточность и зачастую несвоевременность работ по надзору и уходу за древесными насаждениями. Установленные санитарные показатели состояния древесных растений характеризуют их как условно устойчивые.

3. Города с наибольшим совокупным хозяйственно-техносферным потенциалом - Поворино, Борисоглебск, Балашов - характеризуются более ослабленным санитарным состоянием древесных растений в основных функциональных зонах, где постоянно находится население. Снижение показателей состояния древесных растений обусловливает лимитирование устойчивости, а также экологической эффективности урбоэкосистем в качестве основных элементов наземных экологических каркасов в рассмотренных населенных пунктах Воронежской и Саратовской областей.

4. Древесные растения, произрастающие в составе экосистем в пригородных зонах, также испытывают антропогенное давление. Достоверно превышающие значения средних арифметических процентов повреждений древостоев в сравнении с соответствующими контрольными данными связаны с хозяйственной и рекреационной нагрузкой. Растения, располагающиеся в непосредственной близости к автомагистралям и железнодорожным путям, топливным трубопроводам и к другим инженерно-техническим и хозяйственным сооружениям, в большей мере испытывают механические и химико-токсические повреждения. По сравнению с участками экосистем с минимальными техногенными нагрузками растения в непосредственных зонах влияния указанных объектов в большей степени подвержены усыханию ветвей, повреждению листьев и других вегетативных органов болезнями и вредителями (по аналогии с селитебными и индустриальными функциональными зонами городских поселений). Тем не менее ограниченный характер природопользования и хозяйственной нагрузки позволяет древесные растения в фитоценотическом контексте отнести к категории условно устойчивых.

5. Наилучшим экологическим состоянием характеризуются древесные растения, произрастающие в составе естественных экосистем с минимальными значениями антропогенных нагрузок (контрольные участки). Средние арифметические параметры их состояния в максимальной мере позволяют им реализовывать свой биоэкологический потенциал в данных экосистемах. Обладая необходимой биологической устойчивостью, эти организмы способны в полной мере выполнять природные - биоценотические функции, а также роль своеобразных резерватов биологического и генетического разнообразия для местных экологических систем.

6. Установлены ряды древесных растений по возрастанию биологической устойчивости к неблагоприятным условиям среды обитания. В естественных условиях отмечен некоторый «разброс» значений санитарных показателей анализируемой группы организмов вследствие специфики самих биогеоценотических условий, некоторого различия почвенно-экологических и орографических особенностей ландшафтов в пригородах и в удаленных от районных центров территориях. То есть аналогичный тренд не выявлен. Тем не менее средние арифметические значения процентов повреждений древесных растений значительно ниже аналогичных санитарных параметров этих организмов в урбанизированных экосистемах.

7. С учетом расстроенности древесных насаждений и выявленных показателей их санитарного состояния требуются безотлагательные мероприятия по ее устранению.

На основе проанализированных сведений о санитарном состоянии сформулированы такие ключевые предложения.

1. В исследованных населенных пунктах необходимо нормативно и организационно-административно обеспечить эффективный надзор за санитарным состоянием древесных растений и местами их произрастаний, в том числе с привлечением профессионалов и ученых данного профиля.

2. Целесообразны меры по компенсационному озеленению и обновлению зеленых насаждений, в том числе с привлечением видов из местной дендрофлоры с требуемыми показателями устойчивости к заболеваниям, к воздействию вредителей и неблагоприятных погодно-климатических и антропогенных влияний. Остро нуждаются в замене расстроенные древесные насаждения, а также экземпляры с высокими значениями усыхания и старовозрастные особи в пределах санитарно-защитных зон, зон санитарной охраны, транспортных зон. В частности, с помощью видов древесных растений из выделенных групп средней и высокой устойчивости можно успешно (в ландшафтно-планировочном, эстетическом, защитно-экологическом, эколого-реабилитационном контекстах) оптимизировать состав и структуру местных урбоэкосистем в пределах селитебных и индустриальных зон.

3. На территории исследований при подборе посадочного ассортимента для озеленения придорожных участков, производственных зон, прилегающих территорий к объектам энергетики, инженерным коммуникациям, автостоянкам, топливохранилищам, АЗС, авторемонтным пунктам, местам хранения отходов, сброса сточных вод, подъездам к общественно-деловым и социальным объектам предпочтение следует отдавать древесным растениям из группы высокой биологической устойчивости. Также с помощью этих растений в форме живых изгородей, куртин, биогрупп представляется возможность обособить экологически опасные объекты. Организация таких буферных зон в разных частях городов и поселков будет способствовать улучшению экологической обстановки на местном уровне.

4. В зонах рекреации необходимо насытить имеющиеся озеленительные композиции различными представителями местной дендрофлоры, включительно из числа исследованных в рамках настоящей работы. В экологическом и планировочном плане также желательно создание новых рекреационных объектов (скверов, садов, мини-парков, многопрофильных аллей), особенно вблизи общественно-деловых, инженерно-инфраструктурных и жилых объектов.

5. На уровне муниципальных районов территории исследований требуется создать систему круглогодичного контроля за качеством озеленения, агротехнических приемов и эффективности ухода за древес- 
Сираева И.С., Ларионов М.В., Ларионов Н.В., Солдатова В.В., Громова Т.С., Ермоленко А.С., Кулагина Е.Ю. Экологическая оценка санитарных показателей древесных растений в природных и техногенных...

Общая биология Экологическая оценка санитарных по яния древесных растений в составе различных насаждений будут свидетельствовать также и об уровне ухода за ними, об эффективности мер охраны.

6. В лесовосстановительных работах, в особенности в лесных массивах рекреационного, эксплуатационного, водоохранного, почвозащитного целевых назначений, необходимо дополнительно предусмотреть высадку древесных растений из групп средней и высокой устойчивости с соблюдением и максимально возможным сохранением местной специфики видовой и вертикальной структуры сообществ.

7. На всей исследованной территории как в урбаносреде, так и в природных условиях целесообразно обеспечить охрану древесных растений. Для этого в городах и поселках, в их окрестностях уместно ужесточить требования к природопользованию, к его регулированию, к содержанию и охране насаждений, как в соответствии с местными материалами землеустройства, пользования зелеными зонами, лесоустройства, так и на основе результатов оценки санитарного состояния древесных растений. В пригородных и в удаленных от поселений районах рационально ограничить рекреационное и эксплуатационно-хозяйственное лесопользование с выделением для этого специальных зон с обязательным благоустройством, восстановительными и эколого-надзорными мероприятиями на принципах перманентности и всеобщности территориального охвата.

8. Результаты оценки санитарного состояния древесных растений полезно использовать при разработке и внедрении системы комплексного анализа факторов дестабилизации биотических и абиотических компонентов урбаносреды и экологической комфортности для жизни, труда и отдыха местных жителей.

\section{Список литературы:}

1. Леонова Н.А., Ильин В.Ю. Растительный покров и редкие животные Окско-Донской равнины в пределах Пензенской области // Известия высших учебных заведений Поволжского региона. Естественные науки. 2017. № 1. С. 71-87.

2. Придорогин М.В., Придорогин В.К., Придорогин Вл.К. Рельеф Окско-Донской равнины и его влияние на экологию садового ландшафта: монография. Мичуринск: Изд-во МичГАУ, 2006. 655 с.

3. Славгородский А.В. Структура гидрофильной флоры и растительности Окско-Донской равнины: дис. ... канд. биол. наук. Борок, 2001. 420 с.

4. Агафонов В.А., Негробов В.В., Кузнецов Б.И., Мозолевский И.В. К оценке растительного покрова Окско-Донской равнины на примере территории междуречья рек Савала и Елань // Вестник ВГУ. Серия: Химия. Биология. Фармация. 2016. № 3. С. 68-73.

5. Учебно-краеведческий атлас Саратовской области / В.В. Аникин, Е.В. Акифьева, А.Н. Афанасьева и др. Саратов: Изд-во Сарат. ун-та, 2013. 144 с.

6. Бухарина И.Л. Биоэкологические особенности древесных растений и обоснование их использования в целях экологической оптимизации урбаносреды: на примере г. Ижевска: дис. ... д-ра биол. наук. Ижевск, 2008. 475 c.

7. Кавеленова Л.М., Малыхина Н.В., Розно С.А., Смирнов Ю.В., Осипова Е.А., Кузнецов Р.В. Эколо- гические особенности некоторых местных и интродуцированных древесных растений в городских насаждениях лесостепи Среднего Поволжья (на примере г. Самары) // Вестник СамГУ - Естественнонаучная серия. 2007. № 8. С. 89-96.

8. Малыхина Н.В., Трофимова Т.А., Кавеленова Л.М. К оценке составляющих фитопатологического статуса древесных растений в городских насаждениях г. Самары // Известия Самарского научного центра PAH. 2009. T. 11, № 1 (4). C. 796-799.

9. Ioos R., Santini A., Luchi N. Fast and reliable molecular methods to detect fungal pathogens in woody plants // Applied Microbiology and Biotechnology. 2020. P. 1-16. DOI: 10.1007/s00253-020-10395-4.

10. Roy R. Stress physiology of woody plant. Boca Raton: CRC Press, 2019. 284 p.

11. Straigyte L., Zalkauskas R., Pilkauskas M., Sasnauskiene J. Diversity and Condition of Woody Plants in Raseiniai Green Areas // Rural development 2009: the fourth international scientific conference, At Akademija, Kaunas region, Lithuania: proceedings. Akademija: Lithuanian University of Agriculture. 2009. Vol. 4. P. 201-204.

12. Боговая И.О., Теодоронский В.С. Озеленение населенных мест: учеб. пособие. М.: Лань, 2014. 256 с.

13. Серебрякова Н.Е., Гаврицкова Н.Н., Г Граница Ю.В., Медведкова Е.А. Санитарное состояние и декоративность древесных насаждений г. Нижнекамска // Рос. журн. приклад. экол. 2015. № 3. С. 18-24.

14. Кузьмичев А.М., Овчаренко А.А. Оценка засухоустойчивости древесных насаждений в Среднем Прихоперье // Известия Самарского научного центра PAH. 2012. T. 14, № 1. C. 1971-1974.

15. Разинкова А.К. Патологическое состояние древесной растительности парковых насаждений г. Воронежа // Современные проблемы науки и образования. 2014. № 1. - https://science-education.ru/ru/article/ view?id=11286.

16. Федоров В.В. Планировка и застройка населенных мест: учеб. пособие. М.: ИНФРА-М, 2010. 133 с.

17. Мозолевская Е.Г., Катаев О.А., Соколова Е.С. Методы лесопатологического обследования очагов стволовых вредителей и болезней леса. М.: Лесная пром-ть, 1984. 152 с.

18. О «Методических рекомендациях по оценке жизнеспособности деревьев и правилам их отбора и назначения к вырубке и пересадке»: постановление Правительства Москвы от 30.09.2003 г. № 822-ПП // Вестник мэра и Правительства Москвы. 2003. № 58. - https://base.garant.ru/380544.

19. Оценка жизнеспособности деревьев и правила их отбора и назначения к вырубке и пересадке: учеб.метод. пособие / Е.Г. Мозолевская, Г.П. Жеребцова, Э.С. Соколова и др. М.: Изд-во ГОУ ВПО МГУЛ, 2007. $40 \mathrm{c}$

20. Шихова Н.С. Мониторинг состояния кустарниковых насаждений в условиях урбоэкосистем // Классификация и динамика лесов Дальнего Востока: материалы междунар. конф. (Владивосток, 5-7 июня 2001 г.). Владивосток: Дальнаука, 2001. С. 181-182.

21. Шихова Н.С., Полякова Е.В. Деревья и кустарники в озеленении города Владивостока. Владивосток: Дальнаука, 2006. 236 с.

22. Пузаченко Ю.Г. Математические методы в экологических и географических исследованиях. М.: Академия, 2004. 416 с. 


\title{
ENVIRONMENTAL ASSESSMENT OF HEALTH INDICATORS OF WOODY PLANTS IN NATURAL AND MAN-MADE CONDITIONS
}

(C) 2020

\author{
Siraeva Irina Salavatovna, postgraduate student of Botany and Ecology Department \\ Saratov State University (Saratov, Russian Federation) \\ Larionov Maxim Viktorovich, doctor of biological sciences, associate professor, \\ professor of Biology and Ecology Department \\ Balashov Institute of Saratov State University (Balashov, Saratov Region, Russian Federation) \\ Larionov Nikolai Viktorovich, candidate of biological sciences, director \\ Secondary School № 2 of Kotelniki (Kotelniki, Moscow Region, Russian Federation) \\ Soldatova Valeria Viktorovna, postgraduate student of Botany and Ecology Department \\ Gromova Tatyana Sergeevna, postgraduate student of Botany and Ecology Department \\ Ermolenko Anna Sergeevna, postgraduate student of Botany and Ecology Department \\ Saratov State University (Saratov, Russian Federation) \\ Kulagina Ekaterina Yurievna, candidate of biological sciences, \\ associate professor of Biology and Ecology Department \\ Vladimir State University (Vladimir, Russian Federation)
}

\begin{abstract}
The indicators of the sanitary condition of woody plants in the conditions of natural and artificial ecosystems of the Voronezh and Saratov Regions were established and analyzed. In suburban ecosystems of the research area, the state of woody plants is determined at the level of weak damage. In suburban areas of Balashov with the greatest economic and technosphere potential, woody plants reach an average (moderate) degree of damage. In remote relatively preserved ecosystems (control parameters), the state of these organisms corresponds to a weak ecological diagnostic criterion. According to the identified average arithmetic sanitary indicators in the Voronezh Region, the best condition is characterized by woody plants in the ecosystems of Novohopersk and Gribanovsky, in the Saratov Region - in Turki and Samoylovka. There were also significant differences in the arithmetic mean parameters of the sanitary condition of this group plants representatives differentiated by functional zones. The highest damage values are typical for woody plants in the urban ecosystems of industrial zones. The maximum danger to woody plants was observed within these zones in Povorino, Borisoglebsk, and Balashov with high-level average values of damage to these organisms. Significant concern is also caused by the defeat of the analyzed group of organisms in these cities as part of the ecosystems of the settlement zones. The results of the assessment of the sanitary condition of woody plants should be used as a scientific basis for landscaping, environmental protection and reforestation. Measures are proposed to improve the condition of woody plants in various types of ecosystems in the research area. According to the sanitary state of these organisms, it is possible to determine the limits of sustainability of ecological frameworks and differentiate the parameters of environmental comfort for the local population in different territorial categories.

Keywords: municipal districts of Voronezh Region; municipal districts of Saratov Region; natural ecosystems; artificial ecosystems; recreation zones; settlement zones; industrial zones; sanitary condition of woody plants; values and levels of plant degradation; territorial differences in plant viability; trends in plant biological stability; environmental quality; values of environmental comfort for residents; relevance of measures for plant protection.
\end{abstract}

$* * *$

УДК 595.772

DOI 10.24411/2309-4370-2020-11117

Статья поступила в редакцию 23.01.2020

\section{LEGS MORPHOMETRIC CHARACTERS OF THE DOLICHOPUS LATREILLE SPECIES, 1796 (DIPTERA, DOLICHOPODIDAE)}

(C) 2020

\author{
Chursina Mariya Alexandrovna, candidate of biological sciences, \\ senior lecturer of Biology of Plants and Animals Department \\ Voronezh State Pedagogical University (Voronezh, Russian Federation) \\ Negrobov Oleg Pavlovich, doctor of biological sciences, \\ professor of Ecology and Systematics of Invertebrate Animals Department \\ Voronezh State University (Voronezh, Russian Federation)
}

\footnotetext{
Abstract. A comparative analysis of 30 species of the Dolichopodidae family in a phylogenetic context was conducted to examine interspecific variation in the legs morphometry. Five relative traits of legs from 12 and seven absolute traits from nine showed significant phylogenetic signal. A set of traits, such as relatively short hind tibia and relatively long fore and middle tibia and the first segments of the hind legs allowed to allocate Dolichopus species from the other ones. The projection of the phylogenetic tree of Dolichopus species into the morphospace allowed us to divide it into four individual areas: not closely related species, but species having similar modifications of males' legs tended to cluster. This suggests that the legs morphometric traits should be mainly under pressure of sexual selection. It has also been revealed that the elongation of the first segment of hind tarsi in Dolichopus species is associ-
} 